\title{
The effect of high glucose on polyol pathway activity and myoinositol metabolism in cultured human endothelial cells
}

\author{
G.C.Hawthorne ${ }^{1}$, K. Bartlett ${ }^{2}$, C.S. Hetherington ${ }^{1}$ and K.G.M.M.Alberti ${ }^{1}$ \\ ${ }^{1}$ Departments of Medicine and ${ }^{2}$ Child Health, University of Newcastle upon Tyne, The Medical School, UK
}

\begin{abstract}
Summary. Cultured human endothelial cells were incubated with high glucose $(27.5 \mathrm{mmol} / 1)$ supplemented medium for 0 , $2,6,12,24$ and $48 \mathrm{~h}$. Lactate dehydrogenase was assayed as a measure of cell number. Sorbitol and myoinositol were determined as trimethyl silyl derivatives using gas chromatography mass spectrometry. Sorbitol, after an initial lag phase of $2 \mathrm{~h}$, accumulated rapidly to plateau at 2 to 3 fold control value by $24 \mathrm{~h}$, no further increase being seen over a further $24 \mathrm{~h}$ (Baseline, $1.31 \pm 0.36,24 \mathrm{~h} 3.50 \pm 0.74 \mathrm{pmol}$ sorbitol/ unit lactate
\end{abstract}

dehydrogenase; $p<0.001)$. There was no change in myoinositol levels over the $24 \mathrm{~h}$ period. Sorbitol accumulation occurred at glucose concentration $>18.1 \mathrm{mmol} / 1$ and only returned to baseline levels after $24 \mathrm{~h}$ of incubation in normal medium (glucose levels $5.9 \mathrm{mmol} / \mathrm{l}$ ). Sorbitol levels are increased by incubation of endothelial cells at high glucose levels but myoinositol levels remain unchanged.

Key words: Sorbitol, myoinositol, endothelial cells
In both diabetic macro- and microangiopathy, interest has focused on the metabolism of the endothelial cell and its response to high glucose levels. Chronic hyperglycaemia appears to be one major common pathway in the development of all diabetic complications [1,2]. A postulated common mechanism is hyperglycaemia activating the polyol pathway, depleting myoinositol and reducing $\mathrm{Na}^{+} / \mathrm{K}^{+}$ATPase activity. This postulated mechanism has the advantage of explaining diabetic complications in a range of tissues [3].

There is evidence that cultured capillary endothelial cells contain free intra cellular glucose [4], and studies have been undertaken to establish if polyol pathway activation occurs in endothelium. These have demonstrated sorbitol accumulation by $10 \mathrm{~h} \mathrm{[5],} \mathrm{but} \mathrm{after} 24 \mathrm{~h}$ no further increase in level is seen over a period of 14 days [6]. These finding contrast with those in cultured neuroblastoma cells in which sorbitol continues to increase for up to 6 weeks of culture in high glucose media. By two weeks, in this system, myoinositol levels have decreased by 50\% [7]. If the time scale for sorbitol accumulation is shorter in the endothelial cell, myoinositol depletion if it occurs, might be expected to occur more quickly particularly if depletion is linked to sorbitol accumulation.

We have, therefore, investigated the effect of high glucose on sorbitol and myoinositol concentrations in cultured human endothelial cells over $48 \mathrm{~h}$, to determine: (1) if the accumulation of sorbitol and the depletion of myoinositol occurs and, (2) if so, whether these processes are temporally related.

\section{Materials and methods}

\section{Materials}

M199 fetal bovine serum, penicillin, streptomycin, fungizone and glutamine were obtained from Flow Laboratories, (Rickmansworth, UK). Heparin, gelatin and endothelial cell growth supplement were from Sigma Chemical, (Poole, Dorset, UK). N-O-trimethylsilylacetamide (BSA) was from Pierce Chemicals (Chester, UK).

\section{Cell culture and experimental design}

Primary cultures of endothelial cells were established from human umbilical veins obtained from umbilical cords at delivery (with permission from Newcastle upon Tyne Health Authority Ethical Committee $[8,9]$. Cells were cultured in M199 with $20 \%$ fetal bovine serum, endothelial cell growth supplement $150 \mu \mathrm{g} / \mathrm{ml}$, heparin $90 \mu \mathrm{g} / \mathrm{ml}$ supplemented with $2 \mathrm{mmol} / 1$ glutamine, penicillin $50 \mathrm{U} / \mathrm{ml}$, streptomycin $50 \mu \mathrm{g} / \mathrm{ml}$ and fungizone $0.25 \mu \mathrm{g} / \mathrm{ml}$ in $95 \%$ air $/ 5 \% \mathrm{CO}_{2}$.

Confluence was obtained on $25 \mathrm{~cm}^{2}$ flasks coated with $1 \%$ gelatin. At confluence, cells were split $1: 3$ using $0.25 \%$ trypsin in $0.02 \%$ EDTA. Media were changed twice weekly. All cultures were used within 3 weeks of establishing primary cultures and at 3 rd passage.

Cells were identified by morphologic criteria using light microscopy. Their nature was confirmed by both the demonstration of Factor VIII antigen staining by immunofluorescence and by electron microscopy. M199 was supplemented with glucose and the final concentration of glucose confirmed using a Yellow Springs Instruments glucose analyser; Model 23AM (Clandon Scientific, Basingstoke, UK); glucose concentration in medium prior to supplementation was $5.9 \mathrm{mmol} / \mathrm{l}$. Medium in each flask was completely aspirated prior to addition of glucose supplemented medium.

Measurements of sorbitol and myoinositol were made after 2,6, 12,24 and $48 \mathrm{~h}$ of exposure to elevated glucose $(27.5 \mathrm{mmol} / \mathrm{l})$ and compared with cells cultured in $5.9 \mathrm{mmol} / 1$ glucose at time 0 and at $48 \mathrm{~h}$. To determine the concentration of glucose in the medium re- 


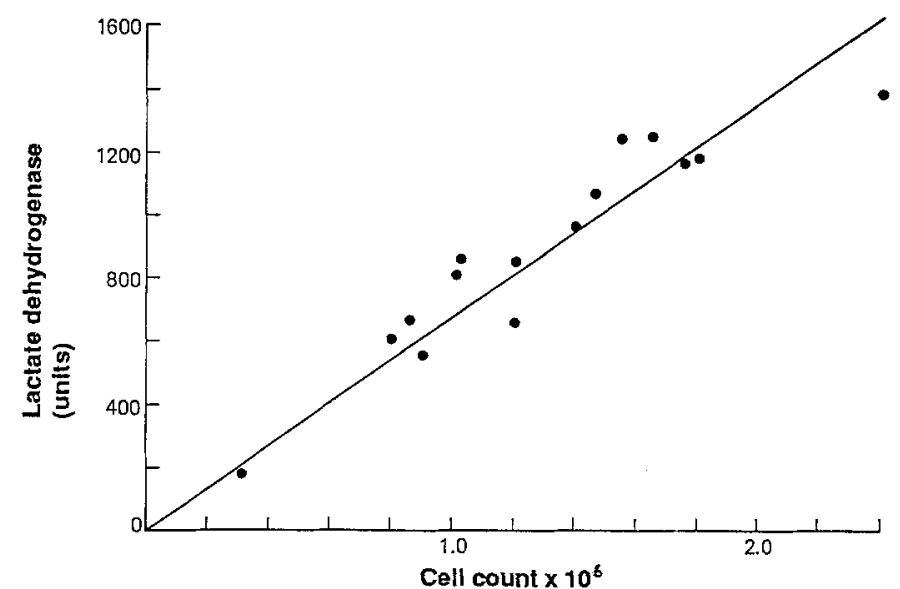

Fig. 1. Plot of lactate dehydrogenase (units) against cell count $\left(10^{6}\right)$. Cells were counted on a modified Neuman haemocytometer. A known number of cells was pelleted and resuspended in extraction buffer. After sonication, the lactate dehydrogenase content of the cell extract was determined. Each value plotted $(\mathbf{O})$ is the cell number with the corresponding lactate dehydrogenase. $(r=0.85)$ Lactate dehydrogenase activity for $1 \times 10^{6}$ cells $=610$ units

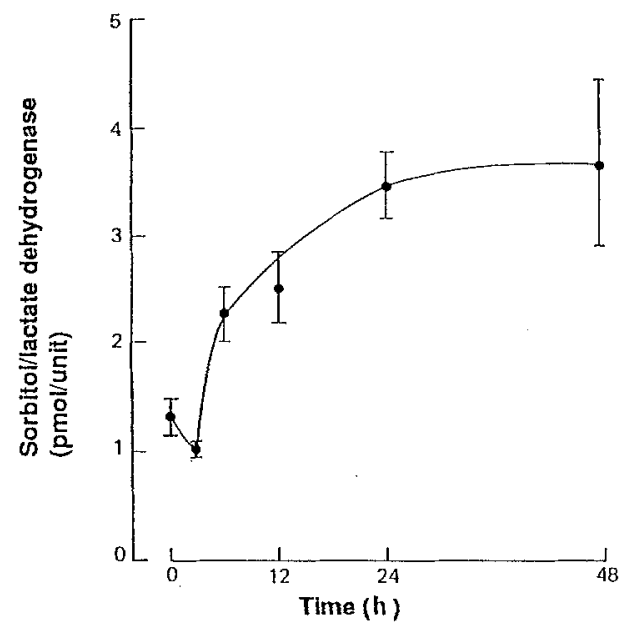

Fig. 2. Sorbitol accumulation after exposure to $27.5 \mathrm{mmol} / \mathrm{l}$ glucose. Each values $(\bullet)$ represents the mean \pm SD of 6 separate determinations except for that at $48 \mathrm{~h}$ where $n=5$. Comparison of $24 \mathrm{~h}$ to baseline value $p<0.001$

quired to cause sorbitol accumulation, cultures were incubated with $11.1,13.7$ and $18.1 \mathrm{mmol} / 1$ glucose for $24 \mathrm{~h}$.

The rate of disappearance of sorbitol was determined by incubating cells with $27.5 \mathrm{mmol} / 1$ glucose for $24 \mathrm{~h}$. The cells were incubated with M199 without glucose supplementation after washing the cultures three times with ice cold phosphate buffered saline $(0.15 \mathrm{mmol} / 1$ $\mathrm{pH} 7.4$ ) and sorbitol was measured at $0,6,12$ and $24 \mathrm{~h}$.

Sorbitol and myoinositol were determined in extracts from endothelial cells. At each time point, culture flasks were cooled on ice, the medium discarded, and the monolayers rapidly washed with ice cold phosphate buffered saline. The wash fluid was carefully and completely aspirated and $1 \mathrm{ml}$ of extraction buffer $(50 \mathrm{mmol} / 1$ Tris, $100 \mathrm{mmol} / 1 \mathrm{KCI}, 20 \mathrm{mmol} / 1 \mathrm{EDTA}, 25 \mathrm{mmol} / 1 \mathrm{NaF}, 1 \% \mathrm{NP} 40$ pH 7.8 with $1 \mu \mathrm{mol} / \mathrm{l} \alpha$ methyl glucose) added. For the experiment with differing glucose concentrations and the rate of disappearance of sorbitol, $10 \mu \mathrm{mol} / 1 \alpha$ methyl glucose was added to the extraction buffer. The monolayer was scraped to facilitate cell detachment. The extract was sonicated for $5 \mathrm{~s}$ (MSE, Microcentaur) (Fison, UK) and was centrifuged at $1,200 \mathrm{~g}$ for $5 \mathrm{~min}$ (Beckman Microcentrifuge, High Wycombe, UK) $100 \mu \mathrm{l}$ was removed for lactate dehydrogenase (LDH) determination and the remainder of the extract was stored at $-20^{\circ} \mathrm{C}$ prior to analysis for sorbitol and myoinositol.

\section{Assays}

$\mathrm{LDH}$ was assayed in final conditions $1.2 \mathrm{mmol} / \mathrm{l}$ pyruvate, $0.15 \mathrm{mmol} / 1 \mathrm{NADH}_{2}, 5 \mathrm{mmol} / 1$ EDTA, $50 \mathrm{mmol} / 1$ Tris $\mathrm{pH} 7.4$ on a centrifugal analyser at $37^{\circ} \mathrm{C}$ [10] (Cobas Bio, Roche Diagnostics, Welwyn Garden City, UK).

To correlate LDH with cell number, confluent flasks were trypsinised with $0.25 \%$ trypsin in $0.02 \%$ EDTA and cells counted using a modified Neuman haemocytometer. After counting the cells were pelleted, resuspended in $1 \mathrm{ml}$ extraction buffer, sonicated and centrifuged. LDH was determined as above.

\section{Myoinositol and sorbitol}

Samples for measurement for analysis were mixed with Duolite MB 5113 resin in $\mathrm{H}+$ and acetate form and aliquots transferred to 'reacti' vials. The samples were evaporated to dryness under nitrogen and placed in a dessicator for at least $30 \mathrm{~min}$ prior to derivatisation. $100 \mu \mathrm{l}$ of derivatising agent (pyridine: trimethylchlorosilane: BSA $2: 1: 1$ ) was added to each dried sample and immediately sealed with teflon caps. The vials were heated to $60^{\circ} \mathrm{C}$ for $30 \mathrm{~min}$ and left to cool in a dessiccator prior to gas chromatography - mass spectrometry (GC/MS) analysis [11].

Chemical ionisation gas chromatography - mass spectrometry using methane as reagent gas and helium as carrier was used. A Finnigan MAT 1020 chemical ionisation instrument (Hemel Hempstead, UK) was used under the following conditions: Methane reagent gas 0.35 torr, He carrier gas $1 \mathrm{~cm}^{3} / \mathrm{min}, 30$ metre $\times 0.25 \mathrm{~mm} \mathrm{DB} 5$ capillary glass column (Jones Chromatography, Hengoed, UK). Thermal programming of the gas chromatograph was used to maximise separation. Initial temperature was $160^{\circ} \mathrm{C}$ at injection rising by $10^{\circ}$ $\mathrm{deg} / \mathrm{min}$ to $260^{\circ} \mathrm{C}$ and the column maintained at this temperature for $4 \mathrm{~min}$. Elution times of sorbital and myoinositol were determined by comparison of peaks to a standard, and recovery and quantitation of the sample by comparison to $\alpha$ methylglucose. Sorbitol eluted at $7 \mathrm{~min}$, myoinositol at $8^{1 / 2} \mathrm{~min}$ and $\alpha$ methylglucose at $6 \mathrm{~min} 40 \mathrm{~s}$. Standards of a mixture of sorbitol, myoinositol and $\alpha$ methylglucose were measured each dlay of analysis and after every 10 measurements. The protonated molecular ions used in each analysis were TMS methylglucose M/Z 467.4, TMS sorbitol M/Z 419.7 TMS myoinositol $\mathrm{M} / \mathrm{Z} 433.4$.

\section{Statistical analysis}

All results are presented as mean $\pm \mathrm{SD}$. Differences between groups were sought using Student's unpaired t-test.

\section{Results}

\section{Lactate dehydrogenase and cell number}

In Figure 1, it can be seen that LDH activity correlated closely with cell number $(r=0.85)$. There was no difference in LDH content of cells incubated in high glucose $\left(580 \pm 200\right.$ units $\mathrm{LDH} / 10^{6}$ cells, $\left.n=8\right)$ when compared to cells incubated with control medium ( $640 \pm 110$ units $\mathrm{LDH} / 10^{6}$ cells, $n=8$; not significant).

\section{Sorbitol levels}

Results are expressed as pmol sorbitol/unit LDH (Table 1). To express data per $10^{6}$ cells, the result was multiplied by 610 (see Fig. 1). Figure 2 shows that when endothelial cells were exposed to $27.5 \mathrm{mmol} / 1$ glucose 
Table 1. The effect of glucose concentration on sorbitol accumulation

\begin{tabular}{lll}
\hline $\begin{array}{l}\text { Glucose concentration } \\
\text { in medium (mmol/l) }\end{array}$ & $\begin{array}{l}\text { Sorbitol/lactate } \\
\text { dehydrogenase } \\
\text { pmol/unit }\end{array}$ & $\begin{array}{l}\text { Sorbitol/10 cells } \\
\text { nmol/cell number }\end{array}$ \\
\hline 5.9 & $2.24 \pm 0.32$ & $1.37 \pm 0.20$ \\
11.0 & $1.84 \pm 0.67$ & $1.12 \pm 0.41$ \\
13.7 & $2.25 \pm 0.02$ & $1.37 \pm 0.01$ \\
$18.1^{\mathrm{a}}$ & $3.63 \pm 1.20$ & $2.21 \pm 0.73$ \\
$27.6^{\mathrm{b}}$ & $3.50 \pm 0.74$ & $2.14 \pm 0.45$ \\
\hline
\end{tabular}

Sorbitol content was determined after $24 \mathrm{~h}$ of glucose supplemented medium. Results are shown as the mean \pm SD of 4 separate determinations except where ${ }^{\mathrm{a}} n=5,{ }^{\mathrm{b}} n=6$. The $\alpha$ methyl glucose concentration in the extraction buffer was $10 \mu \mathrm{mol} / 1 . p<0.04$ for the comparison of sorbitol/LDH at concentration $18.1 \mathrm{mmol} / 1$ with $5.9 \mathrm{mmol} / 1$ glucose

Table 2. Sorbitol concentration after $24 \mathrm{~h}$ of $25.5 \mathrm{mmol} / 1$ glucose followed by medium with $5.9 \mathrm{mmol} / \mathrm{l}$ glucose concentration

\begin{tabular}{lll}
$\begin{array}{l}\text { Time } \\
\text { after switch } \\
\text { to normal glucose } \\
\text { (h) }\end{array}$ & $\begin{array}{l}\text { Sorbitol/LDH } \\
\text { pmol/unit }\end{array}$ & $\begin{array}{l}\text { Sorbitol/106 cells } \\
\text { nmol/cell number }\end{array}$ \\
\hline 0 & $3.50 \pm 0.74$ & $2.14 \pm 0.45$ \\
6 & $3.56 \pm 0.25$ & $2.17 \pm 0.15$ \\
12 & $3.48 \pm 1.4$ & $2.12 \pm 0.85$ \\
$24^{\mathrm{a}}$ & $0.92 \pm 0.64$ & $0.56 \pm 0.39$ \\
\hline
\end{tabular}

High glucose containing medium was carefully aspirated and the cell monolayer was washed 3 times with PBS before the addition of normal medium ( $5.9 \mathrm{mmol}$ glucose). Values are shown as the mean $\pm \mathrm{SD}$ of 4 separate determinations. ${ }^{a} p<0.01$ for comparison time 12 and $24 \mathrm{~h}$

Table 3. Myoinositol levels after high glucose supplemented medium

\begin{tabular}{lll}
\hline $\begin{array}{l}\text { Time } \\
\text { (h) }\end{array}$ & $\begin{array}{l}\text { Myoinositol/LDH } \\
\text { pmol/unit }\end{array}$ & $\begin{array}{l}\text { Myoinositol } / 10^{6} \text { cells } \\
\text { nmol/cell number }\end{array}$ \\
\hline 0 & $5.20 \pm 4.00$ & $3.17 \pm 2.44$ \\
2 & $4.64 \pm 1.69$ & $2.83 \pm 1.03$ \\
6 & $6.41 \pm 1.41$ & $3.91 \pm 0.86$ \\
12 & $4.11 \pm 2.35$ & $2.51 \pm 1.43$ \\
24 & $4.56 \pm 1.94$ & $2.78 \pm 1.18$ \\
48 & $6.14 \pm 0.58$ & $3.75 \pm 0.35$ \\
\hline
\end{tabular}

Values shown are the mean $\pm \mathrm{SD}$ of 6 separate determinations. The comparison of myoinositol/lactate dehydrogenase at $24 \mathrm{~h}$ and $48 \mathrm{~h}$ to $\mathrm{Oh}$ is not significant

for $6 \mathrm{~h}$ or more, the sorbitol level is significantly increased compared to the sorbitol level at time 0 , $p<0.005$. However, at $2 \mathrm{~h}$, there was a fall in sorbitol concentration, but this was not statistically significant. Thus, there is an apparent initial lag before sorbitol accumulation occurs. Sorbitol accumulation plateaued after $24 \mathrm{~h}$ of high glucose, no further increase in levels being seen at $48 \mathrm{~h}$ (Fig. 2). Although sorbitol only began to accumulate when glucose concentrations were above $13.7 \mathrm{mmol} / 1$ glcusoe for $24 \mathrm{~h}$ (Table 1 ), this did not reflect the rate of sorbitol production at 11.1 and $13.7 \mathrm{mmol} / \mathrm{l}$, as increases in sorbitol production can occur without a detectable increase in tissue sorbitol.
No difference in sorbitol levels was observed between 18.1 and $27.6 \mathrm{mmol} / \mathrm{l}$.

Once sorbitol had accumulated within the cell, and even after the surrounding medium concentration of glucose had been decreased to $5.9 \mathrm{mmol} / 1$, sorbitol persisted within the cells for up to $12 \mathrm{~h}$. Levels fell to baseline levels at $24 \mathrm{~h}$ (Table 2).

\section{Myoinositol}

Myoinositol values are tabulated in Table 3. There was no significant change in myoinositol concentration in endothelial cells treated with $27.5 \mathrm{mmol} / 1$ glucose over $24 \mathrm{~h}$.

\section{Discussion}

Activation of the polyol pathway with subsequent myoinositol depletion and reduction in $\mathrm{Na}^{+} / \mathrm{K}^{+}$ATPase activity as a result of hyperglycaemia has been postulated as a common mechanism by which longterm diabetic complications develop in many tissues [3]. This theory avoids the problem that sorbitol accumulation in most tissues is not high enough to be osmotically significant [12] and consequently attributes complications to myoinositol depletion resulting from sorbitol accumulation. In neural tissue from both human and animal chronic diabetic models, myoinositol depletion is seen as an accompaniment of sorbitol accumulation in the presence of hyperglycaemia [12-15]. In cultured neuroblastoma cells, these observations were extended to show that although sorbitol accumulation plateaus at 6 weeks, myoinositol depletion occurs well before this time. This led Yorek to postulate that myoinositol depletion was not due to competitive inhibition by glucose for myoinositol uptake but due to a decrease in high affinity myoinositol uptake possibly modulated by the presence of sorbitol [7]. When sorbitol production is blocked with an aldose reductase inhibitor, myoinositol depletion is avoided [16]; this tends to confirm Yorek's postulate as plasma glucose levels are not altered.

Although the above is true for neural tissue, in endothelial cells the picture is less clear. We report sorbitol values of $0.79 \pm 0.09$ SEM nmoles $/ 10^{6}$ cells control rising to $2.06 \pm 0.27 \mathrm{SEM}$ nmoles $/ 10^{6}$ cells. These findings differ by an order of magnitude from Lorenzi who found $0.04-0.12$ nmoles $/ 10^{6}$ cell rising to $0.08-0.38 \mathrm{nmol} / 10^{6}$ cells in the presence of $20 \mathrm{mmol} / 1$ glucose [6]. Another report gives values of 18 nmoles sorbitol/flask culture after $10 \mathrm{~h}$ high glucose. Both Koh [5] and Lorenzi [6] used the sorbitol dehydrogenase assay at the lower limit of sensitivity, and cell number was not directly measured. By measuring $\mathrm{LDH}$, we quantified the amount of cellular material present and made all measurements with selected ion screening on $\mathrm{GC} / \mathrm{MS}$, a more sensitive method. Despite this, the intracellular sorbitol levels reported are not osmotically significant. Sorbitol accumulates quickly after $6 \mathrm{~h}$ of incubation, but no further increase was seen after $24 \mathrm{~h}$. 
However, despite this increase in sorbitol accumulation in response to higher glucose, the overall proportion of glucose converted into sorbitol had fallen (control sor$\mathrm{bitol} /$ glucose $=0.2$, at $24 \mathrm{~h}$ sorbitol $/$ glucose $=0.13$ ), i. e. glucose concentration has increased 6 fold but sorbitol accumulation only $2-3$ fold. This suggests that in hyperglycaemia the polyol pathway in endothelial cells is activated but is saturable and is not the main method for coping with an increase in intracellular glucose. Previous studies have shown that high glucose does not induce the enzymes of the pentose phosphate shunt and malic enzyme [17]. This suggests that increased intracellular glucose either remains free or as glucose 6 phosphate [6] - a substance with increased potential for nonenzymatic glycation.

However, these findings must be interpreted cautiously. Not only are the endothelial cells at 3rd passage and from umbilical vein, but also, they are grown in the presence of fetal bovine serum. Castration of diabetic rats markedly diminishes granulation tissue levels of sorbitol and completely prevents decrease in tissue levels of myoinositol [18]. It might be reasoned that the in vitro model studied reflects the castrate or prepubertal situation more closely than the normal adult and that studies should be repeated in the presence of sex steroids.

Depletion of myoinositol has been demonstrated mainly in neural tissue after chronic hyperglycaemia. We did not show any alteration in myoinositol concentration over $24 \mathrm{~h}$ in endothelial cells. The reasons for this might be that: (a) myoinositol depletion is specific to neural tissue; (b) the experiment did not continue for long enough; (c) the absence of sex steroids to mediate depletion. Myoinositol supplementation of media has been shown to increase endothelial cell proliferation but the proliferative delay induced by high glucose concentrations is not corrected by myoinositol supplementation of the medium over 14 days [19]. In the short term experiment described, there was no evidence of depletion of myoinositol. Taken together these findings indicate that myoinositol depletion is not the mechanism by which high glucose causes delay in endothelial cell proliferation.

In conclusion, although sorbitol accumulates to 2-3 fold control value in endothelial cells exposed to high glucose, myoinositol depletion does not occur. This suggests that in endothelial cells the polyol pathway has a minor role, and the role of free intracellular glucose and glucose-6-phosphate should be further investigated.

Acknowledgements. G.C. Hawthorne is a Medical Research Training Fellow. This Study was supported by a British Diabetic Association grant. We are grateful to Dr's T. Lind and P. Whittaker for their help in providing human umbilical cords.

\section{References}

1. Barbarosa J, Saner B (1984) Do genetic factors play a role in the pathogenesis of diabetic microangiopathy? Diabetologia 27 : 487-492
2. Feingold KF, Lee TH, Chang MY, Siperstein HD (1986) Muscle capillary basement membrane width in patients with induced diabetes mellitus. J Clin Invest 78: 102-107

3. Winegrad AI (1987) Does a common mechanism induce the diverse complications of diabetes? Diabetes 36: 396-406

4. Betz AL, Bowman PD, Goldstein GW (1983) Hexose transport in microvascular endothelial cells cultured from bovine retina. Exp Eye Res 36: 269-277

5. Koh MS, Misch KJ, Yuen CT, Rhodes EL (1986) Accumulation of sorbitol in endothelial cells - a possible cause of diabetic microangiopathy. Diab Res 3: 217-219

6. Lorenzi M, Toledo S, Boss GR, Lane MJ, Montisano DF (1987) The polyol pathway and glucose-6-phosphate in human endothelial cells cultured in high glucose concentrations. Diabetologia 30 : 222227

7. Yorek MA, Dunlop JA, Ginsberg BH (1987) Myoinositol metabolism in $41 \mathrm{~A} 3$ neuroblastoma cells; effects of high glucose and sorbitol levels. J Neurochem 48: 53-61

8. Gimbrone MA Ir (1976) Culture of vascular endothelium. In: Spaet TH (ed) Prog in Haem Thromb, Vol 3. Grune and Stratton, New York, pp 1-2.8

9. Jaffe IEA, Nachhman RL, Becker GC, Minick CR (1973) Culture of human endothelial cells derived from umbilical veins - identification by morphological and immunological criteria. J Clin Invest 52: $2745-2756$

10. Committee on Enzymes of the Scandinavian Society for Clinical Chemistry and Clinical Physiology (1974) Recommended methods for the determination of four enzymes in blood. Scand J Clin Lab Invest 33: 291-306

11. Laker MF (1979) Estimation of disaccharides in plasma and urine by gas-liquid chromatography. I Chromatog 163: 9-18

12. MacGregor LC, Rosecan LR, Laties AM, Matschinsky FM (1986) Altered retinal metabolism in diabetes. J Biol Chem 261: 4046-4051

13. Finegold D, Lattimer SA, Nolles S, Bernstein M, Greene DA (1983) Polyol pathway activity and myo-inositol metabolism. Diabetes 32: 988-992

14. Mayhew JA, Gillon KRW, Hawhorne JN (1983) Free and lipid inositol, sorbitol and sugars in sciatic nerve obtained post-mortem from diabetic patients and control subjects. Diabetologia 24: 13-15

15. Hales PJ, Nattrass M, Silverman SH, Serrit C, Perkins CM, Uden A, Sundkint G (1987) Peripheral nerve concentrations of glucose, frucutose, sorbitol and myoinositol in diabetic and non-diabetic patients. Diabetologia 30: 464-467

16. Williamson JR, Chang K, Roswold E, Marvol J, Tomlinson M, Sherman WR, Ackermann KE, Kilo C (1985) Sorbitol prevents diabetes-induced increases in vascular permeability but does not alter collagen crosslinking. Diabetes 34: 703-705

17. Hawthorne GC, Alberti KGMM (1988) The effect of high glucose and high insulin concentrations on pentose phosphate shunt enzymes and malic enzymes in cultured human endothelial cells. Horm Metab Res 20: 645-647

18. Williamson JR, Roswold E, Chang K, Marvel J, Tomlinson M, Sherman WR, Ackermann KE, Berger RA, Kilo C (1986) Scx steroid dependency of diabetes - induced changes in polyol metabolism, yascular permeability and collagen cross linking. Diabetes 35: $20-27$

19. Lorenzi M, Toledo S (1986) Myo-inositol enhances the proliferation of human endothelial cells in culture but fails to prevent the dclay induced by high glucose. Metabolism 35: 824-829

Received: 20 September 1988

and in revised form: 13 February 1989

Dr. G.C.Hawthorne

Department of Medicine

University of Newcastle upon Tyne

Framlington Place

Newcastle upon Tyne NE2 4HH

UK 